\title{
Seasonal Variation of the Physicochemical Properties of Water Samples in Mahanadi Estuary, East Coast of India
}

\author{
Pravat Ranjan Dixit ${ }^{1}$, Biswabandita Kar ${ }^{1 *}$, Partha Chattopadhyay ${ }^{2}$, Chitta Ranjan Panda ${ }^{2}$ \\ ${ }^{1}$ KIIT University, Bhubaneswar, India; ${ }^{2}$ CSIR-Institute of Minerals and Materials Technology, Bhubaneswar, India. \\ Email: pravatdixit@gmail.com, ${ }^{*}$ karpublications@gmail.com
}

Received December $26^{\text {th }}, 2012$; revised January $30^{\text {th }}, 2013$; accepted March $10^{\text {th }}, 2013$

Copyright (C) 2013 Pravat Ranjan Dixit et al. This is an open access article distributed under the Creative Commons Attribution License, which permits unrestricted use, distribution, and reproduction in any medium, provided the original work is properly cited.

\begin{abstract}
The two major sources which are contributing to marine pollution are natural processes as well as anthropogenic activities. The natural process includes precipitation, erosion, weathering of crystal material whereas anthropogenic activities are urbanization, industrialization, mining and agricultural activities, etc. Mahanadi is the biggest river source of Odisha which joins the Bay of Bengal at Paradip. Paradip Township is an urbanized well-developed industrial township where various anthropogenic activities are contributing pollution to the water sources. In the present study, an attempt has been made to estimate and monitor the seasonal and spatial variation of physiochemical properties of the Mahanadi estuary, the East Coast coastal belt of India. The result revealed that there is a remarkable variation in the physiochemical parameters such as $\mathrm{pH}$, salinity, TSS, DO, BOD, $\mathrm{NO}_{2} \mathrm{~N}, \mathrm{NO}_{3} \mathrm{~N}, \mathrm{NH}_{4} \mathrm{~N}, \mathrm{TN}, \mathrm{TP}, \mathrm{SIO}_{4}$ and Chl-a which are attributed to the runoff water getting discharged to the coastal water sources. It is being recommended to treat waste water and materials before discharging them to the marine water medium.
\end{abstract}

Keywords: Physicochemical; Water; Pollution; Mahanadi Estuary

\section{Introduction}

The marine environment, especially costal and estuary, forms an essential component of the global life. In highly developed countries, all these human activities can affect the characteristics of the water in their estuaries. The environmental impact of municipal wastewater and industrial effluents, discharge on receiving water are numerous and inputs of contaminants can affect the aquatic biota as well as the health of the marine environment [1]. The water quality depends on both natural processes, such as precipitation erosion, weathering of crystal materials and anthropogenic processes like urbanization, industrialization, mining and agricultural activities [2]. These two parameters play a vital role in nutrient cycling, eutrophication, biota abundance and overall food web dynamics in estuarine and near shore ecosystems, whereas surface runoff is a seasonal phenomenon largely affected by climate in the basin. Apart from this, fishing activities near the estuary also influence the water quality. In this context, researchers have analyzed the water quality of Mahanadi River and estuarine system [1,3-7].

*Corresponding author.
The aim of present research is to study the seasonal and special nutrient variation and change in physicochemical parameter due to the impact of pollution sources and industrial effluents upon Mahanadi estuarine environment.

\section{Outlines Study of Sampling Area}

Mahanadi is one of the major rivers of India and is the largest river of Orissa state having the annual discharge of $66,640 \mathrm{Mm}^{3}$. The average annual rainfall is $1572 \mathrm{~mm}$, of which $70 \%$ is precipitated during the southeast monsoon between mid June to mid October. The growth of industrialization and urbanization in the upstream and estuarine region of Mahanadi, is putting unique pressure on estuarine and coastal resources [2,5,7]. The Mahanadi River begins in the Baster hills of Madhya Pradesh flows over different geological formations of Eastern Ghats and adjacent areas and joins the Bay of Bengal after divided into different branches in the deltaic area. The main branches of River Mahanadi meet Bay of Bengal at Paradip (Figure 1). The River basin $\left(80^{\circ} 30^{\prime} \mathrm{E}\right.$ $86^{\circ} 50^{\prime} \mathrm{E}$ and $19^{\circ} 20^{\prime} \mathrm{N}-23^{\circ} 35^{\prime} \mathrm{N}$ ) extends over an area approximately $141,600 \mathrm{~km}^{2}$, has a total length of $851 \mathrm{~km}$ and an annual runoff of $50 \times 10^{9} \mathrm{~m}^{3}$ with a peak dis- 


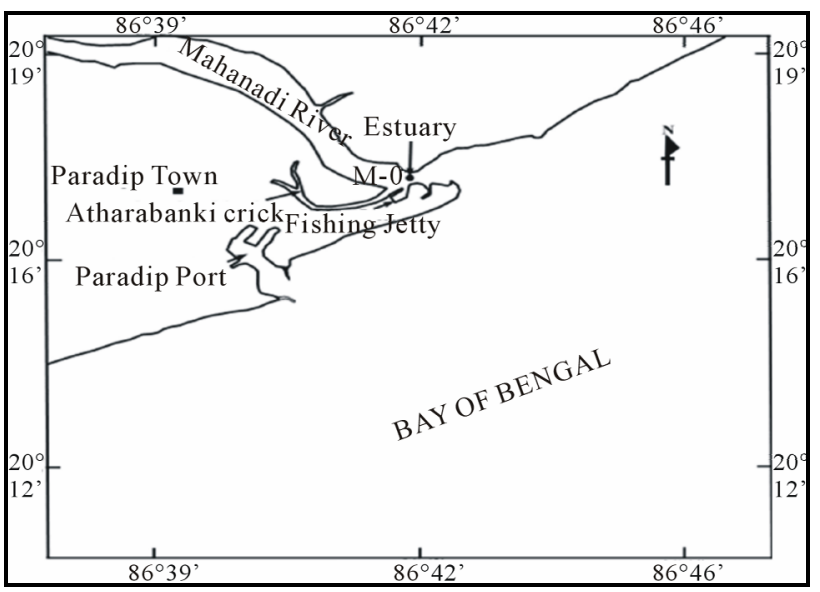

Figure 1. Map showing locations of station in Mahanadi estuary.

charge of $44,740 \mathrm{~m}^{3} \mathrm{~s}^{-1}$ [8-11]. Mahanadi estuary, the major estuary of coastal Orissa has its drainage basin, which is one of the biggest drainage basins along the east Coast. The tidal estuarine part of the river covers a length of $10 \mathrm{~km}$ and has a basin area of $9 \mathrm{~km}^{2}$ [12]. Based on physical characteristics, the estuary has been characterized as a partially mixed coastal plain estuary [13]. Tidal cycle is semidiurnal. It is principally a wave-dominated coast during the southwest monsoon season, while during the non-monsoon period it is mixed wave and tide dominated. Mahanadi estuary receives effluents from two fertilizer plants, other small industries and domestic sewages from Paradip Township. Apart from these, fishing harbour activities at the estuary also affect the water quality. Atharbanki Creek is heavily loaded with the most of the municipal sewage of Paradip Township and effluents from industries. The anthropogenic/port activities influenced the estuarine environment of Mahanadi.

\section{Materials and Methods}

Water samples were collected from the Mahanadi river mouth at a station (Lat. 20 $17^{\prime} 16^{\prime \prime}$ and Long. 86 $\left.42^{\prime} 28^{\prime \prime}\right)$ during 2008-09 to 2009-10 (Figure 1). Diurnal tidal surface sampling was carried out at an interval of $3 \mathrm{hrs}$ in three different seasons such as, pre-monsoon (May) postmonsoon (October) and summer (March). Surface water temperature, $\mathrm{pH}$ were measured in situ by using WTW Kit. Niskin's water sampler will collect water samples. Salinity, TSS, dissolved oxygen (DO) was measured by the standard methods [14]. DO and BOD were done by Winkler's method and BOD was calculated from different in DO concentration after 5 days of incubation at $20^{\circ} \mathrm{C}$. Cellulose nitrate membrane filters of pore size 0.45 $\mu \mathrm{m}$ were used for determination of TSS. Nutrients such as $\mathrm{NO}_{2}-\mathrm{N}, \mathrm{NO}_{3}-\mathrm{N}, \mathrm{TN}, \mathrm{PO}_{4}-\mathrm{P}, \mathrm{TP}$, and $\mathrm{SiO}_{4}-\mathrm{Si}$ were determined by UV-visible spectrophotometer (Perkin Elmer, Lambda 35) as described in methods of seawater analysis [15]. Water samples for Chl-a determination were filtered through Whatmann $\mathrm{GF} / \mathrm{C}$ glass fiber filters and pigment extraction was performed using $90 \%$ acetone. Pigment concentration was measured by means of a UV-visible spectrophotometer for chlorophyll-a analysis [16]. Statistical analysis was carried out by using SPSS VER. 10.0 statistical packages.

\section{Result and Discussion}

The seasonal variations of environmental variables are presented in Table 1. The seasonal water temperature varied from 27.18 to $30.85^{\circ} \mathrm{C}$. During higher temperature in summer followed by post monsoon and pre monsoon, the $\mathrm{pH}$ varied between 7.99 to 8.43 in pre monsoon, post monsoon and summer. The temperature and $\mathrm{pH}$ were recorded lower during the post monsoon seasons. Salinity values fluctuated between 0.01 to 29.36 PSU in premonsoon, post monsoon and summer. The salinity showed a regular trend of variation with tides. The lowest and highest values are always associated with flood and ebb tides. The seasonal variation salinity (0.01 PSU) lowers in Post monsoon, due to the river run off in this period and high dilution in the estuary. The seasonal variation TSS varied from $3.53 \mathrm{mg} / \mathrm{l}$ to $56.88 \mathrm{mg} / \mathrm{l}$. The low tide higher value $(56.88 \mathrm{mg} / \mathrm{l})$ were recorded during post monsoon, which indicates the river run off, industrial effluents and municipal sewage contaminated in the estuary. The seasonal variation of DO values were between $4.74 \mathrm{mg} / 1$ and $8.48 \mathrm{mg} / \mathrm{l}$. The DO values are lowest $(4.74 \mathrm{mg} / \mathrm{l})$ in pre monsoon. The lower concentration of DO values in the estuary indicates that a high or-

Table 1. Seasonal variation of standard deviation (Sd.dev.) values of environmental variables in the Mahanadi estuary of year 2008-2010.

\begin{tabular}{cccc}
\hline & PREMONSOON & POSTMONSOON & SUMMER \\
\hline & Mean \pm Sd.dev & Mean \pm Sd.dev & Mean \pm Sd.dev \\
\hline $\mathrm{pH}$ & $8.15 \pm 0.11$ & $7.77 \pm 0.38$ & $8.04 \pm 0.29$ \\
Salinity & $14.68 \pm 8.23$ & $6.49 \pm 7.04$ & $18.62 \pm 9.07$ \\
$\mathrm{TSS}$ & $15.00 \pm 9.22$ & $16.31 \pm 20.17$ & $11.00 \pm 8.85$ \\
$\mathrm{DO}$ & $7.08 \pm 1.42$ & $7.10 \pm 1.29$ & $7.19 \pm 0.86$ \\
$\mathrm{BOD}$ & $1.82 \pm 0.86$ & $2.09 \pm 0.71$ & $2.04 \pm 1.22$ \\
$\mathrm{NO}_{2}-\mathrm{N}$ & $0.53 \pm 0.22$ & $0.62 \pm 0.30$ & $0.57 \pm 0.37$ \\
$\mathrm{NO}_{3}-\mathrm{N}$ & $2.74 \pm 1.17$ & $3.79 \pm 1.34$ & $3.38 \pm 1.71$ \\
$\mathrm{NH}_{4}-\mathrm{N}$ & $2.63 \pm 1.82$ & $4.79 \pm 1.86$ & $3.46 \pm 1.66$ \\
$\mathrm{TN}$ & $28.01 \pm 10.59$ & $41.02 \pm 10.94$ & $69.75 \pm 36.51$ \\
$\mathrm{PO}_{4}-\mathrm{P}$ & $3.24 \pm 1.15$ & $11.44 \pm 9.68$ & $8.10 \pm 2.81$ \\
$\mathrm{TP}$ & $6.62 \pm 2.92$ & $14.49 \pm 12.12$ & $16.32 \pm 10.93$ \\
$\mathrm{SiO}_{4}$ & $3.54 \pm 1.01$ & $4.34 \pm 1.11$ & $6.53 \pm 2.91$ \\
$\mathrm{Chl}_{-} \mathrm{a}\left(\mathrm{mg} / \mathrm{m}^{3}\right)$ & $2.98 \pm 2.03$ & $4.25 \pm 1.89$ & $1.94 \pm 0.59$ \\
\hline
\end{tabular}

TSS-Total suspended solids, TN-Total nitrogen, TP-Total phosphorus. 
ganic load from the sewage of Paradip port, town ship as well as effluents from fertilizer industry situated upstream of the Mahanadi estuary [6]. The seasonal variations of BOD varies from $0.83 \mathrm{mg} / \mathrm{l}$ and $3.92 \mathrm{mg} / \mathrm{l}$. BOD values highest in post monsoon due to the large amount of municipal sewage wastes, effluents from industries, Atharbanki creek carries all the sewage from Paradip township and industrial effluents from fertilizer industry directly into the estuary in this period.

The seasonal variations of nutrients concentrations during the sampling period ranged between $0.10 \mu \mathrm{mol} / 11$ to $1.16 \mu \mathrm{mol} / 1 \mathrm{NO}_{2}, 1.32 \mu \mathrm{mol} / 1$ to $6.32 \mu \mathrm{mol} / 1 \mathrm{NO}_{3}$, $0.63 \mu \mathrm{mol} / 1$ to $7.93 \mu \mathrm{mol} / 1 \mathrm{NH}_{4}, 17.13 \mu \mathrm{mol} / 1$ to $126.73 \mu \mathrm{mol} / 1 \mathrm{TN}, 1.41 \mu \mathrm{mol} / 1$ to $28.97 \mu \mathrm{mol} / 1 \mathrm{PO}_{4}, 3.84$ $\mu \mathrm{mol} / 1$ to $36.98 \mu \mathrm{mol} / 1 \mathrm{TP}$ and $1.99 \mu \mathrm{mol} / 1$ to 10.55 $\mu \mathrm{mol} / 1 \mathrm{SiO}_{4} . \mathrm{NO}_{2}$ always indicates the fresh input of organic load in to the water system [6]. Municipal sewage loads are accounted as the main source of organic matter for river and estuarine environment. $\mathrm{NO}_{2}$ concentration was higher in post monsoon, which is due to the influx of municipal sewage from Paradip port and township. The $\mathrm{NO}_{2}$ discharge through effluents during indicates that the concentration is diluted during post monsoon season. This phenomenon is also found in the Periyar river estuarine system [9]. The highest concentration $\mathrm{NO}_{3}$ are found in post monsoon, due to the river water and agricultural runoff, Atharbanki creek carries all the sewage Paradip township and industrial effluents from fertilizer industry in to the Mahanadi estuary [17,18]. This phenomenon was observed in the Mahanadi river-estuarine system [6], the Godavari river-estuarine system [19], the Mandovi Zuari river-estuarine system [12] and Periyar river estuarine system [9]. The ammonia concentration is comparatively higher during post monsoon then the pre monsoon and summer. The source of ammonia is from localized anthropogenic input rather then River run-off. The Total nitrogen $(\mathrm{TN})$ concentration is higher in summer, which may be due to the decay of organic debris, disintegration of industrial effluents and organic wastes. The highest concentration $\mathrm{PO}_{4}$ and Total phosphorus recorded in post-monsoon of 2008-09 might be due to the effluent discharge from the near by Phosphatic industries. The spatial and seasonal variation total phosphorus high in summer, which may be that a higher value of organic from of phosphate is contributed through the municipal sewage of Paradip port town and effluents of Phosphatic industries. The seasonal variation show that silicate concentration is maximum during the summer season, probably on account of the input of more siliceous sediment gathered from its catchments area [1,20-22]. The above nutrients were higher in low tide than that of high tide. The minimum DO, BOD and other nutrient our present study were consider as polluted as the estuary, which is one of the most polluted estuaries east cost of India. Land runoff through the river from a large basin is the principal source of nutrient in the coastal water off Paradip, Bay of Bengal. The increase in industrial activities near Paradip found to have adverse impact on health of the Mahanadi river, estuary and its coastal environment. The growth of industrialization and urbanization is in the upstream and estuarine and coastal resources.

Chlorophyll-a concentration revealed wide seasonal variation. Chlorophyll-a varied from 1.35 to $6.92,1.54$ to 7.41 and 0.99 to $2.47 \mathrm{mg} / \mathrm{m}^{3}$ for pre monsoon, post monsoon and summer seasons respectively. Relatively, higher values are also observed during post monsoon season reflects the higher phytoplankton productivity. The variation of Chlorophyll-a content during post monsoon is insignificant and a reverse condition is marked during pre-monsoon season. The chlorophyll-a concentration was observed higher during post monsoons.

\section{Statistical Analysis}

In recent years, various statistical procedures based on multivariate data from river-estuarine system have been used to formulate environmental classification, which helps for a better understanding of the chemical processes and difference in environmental variables, nutrient concentrations in the river-estuarine system. For better understanding of natural and anthropogenic fluxes responsible for characterization of water quality in Mahanadi estuarine system, researchers have carried out statistical analysis of the water quality study $[6,23,24]$. The present study includes the principal component analysis for three seasonal sets of data. $\mathrm{pH}$ shows positive significant correlation with salinity. Salinity shows negative significant correlation with $\mathrm{NH}_{4}$ whereas DO shows negative significant correlation with $\mathrm{BOD}$, and $\mathrm{NO}_{3}$. BOD shows positive significant correlation with $\mathrm{NO}_{2}$, $\mathrm{NO}_{3}$ and $\mathrm{NH}_{4} . \mathrm{NO}_{2}$ has positive significant correlation with $\mathrm{NH}_{4}, \mathrm{PO}_{4}$. $\mathrm{NH}_{4}$ shows positive significant correlation with $\mathrm{PO}_{4}$ whereas $\mathrm{TN}$ produces positive significant correlation with TP and $\mathrm{SiO}_{4}$ and $\mathrm{PO}_{4}$ shows positive significant correlation with TP. The statistical analysis data with its seasons is represented graphically in Figure 2.

\section{Conclusion}

A detailed seasonal variations physicochemical and nutrient content study of the estuarine water of Mahanadi over a period of two years brought out the following facts. The main source of pollutants is the residential one, generating both organic and inorganic wastes. Mahanadi estuary receives effluents from two fertilizer plants, from other small industries and domestic sewages from Paradip Township. Apart from these, fishing harbour 

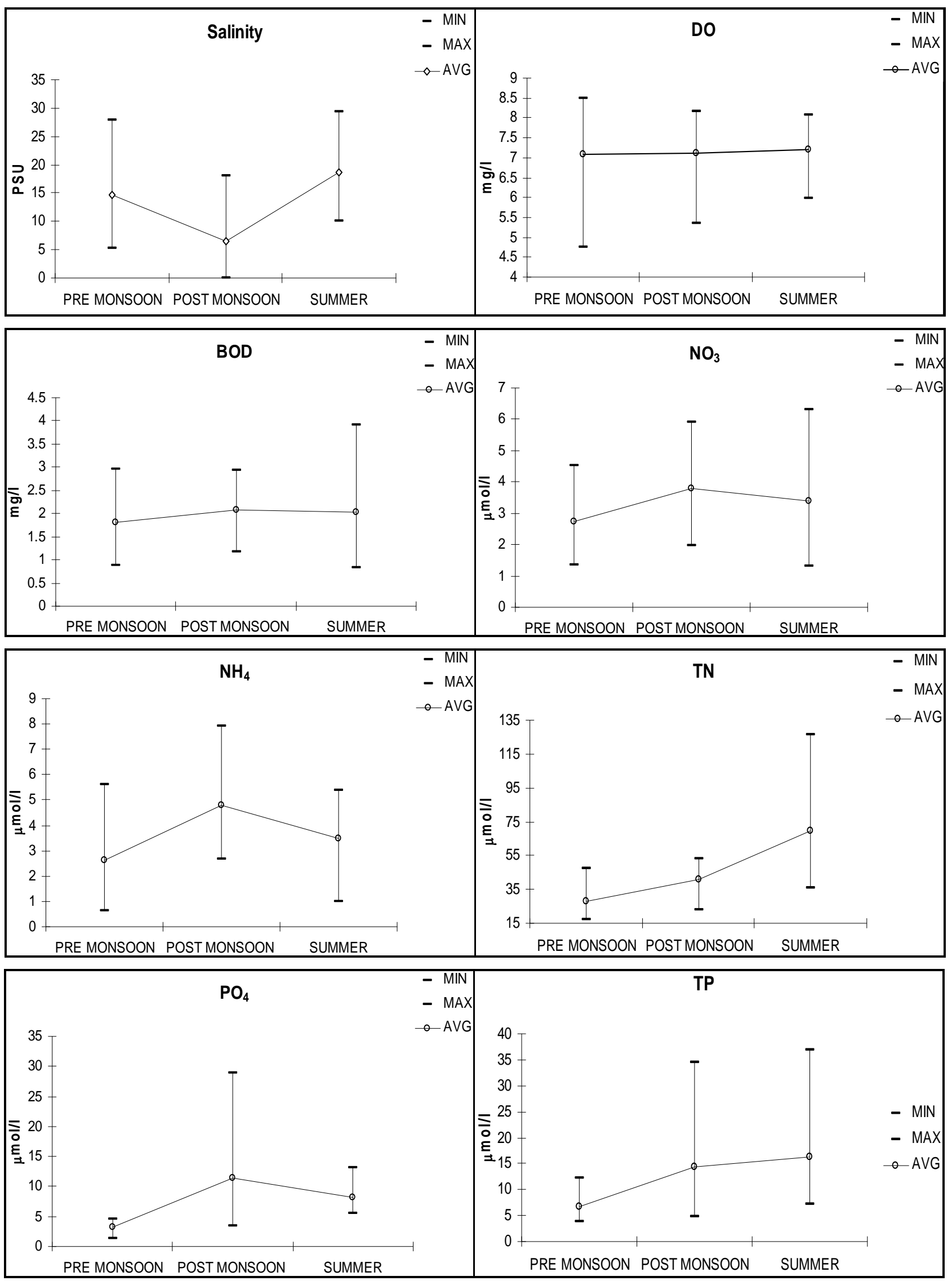


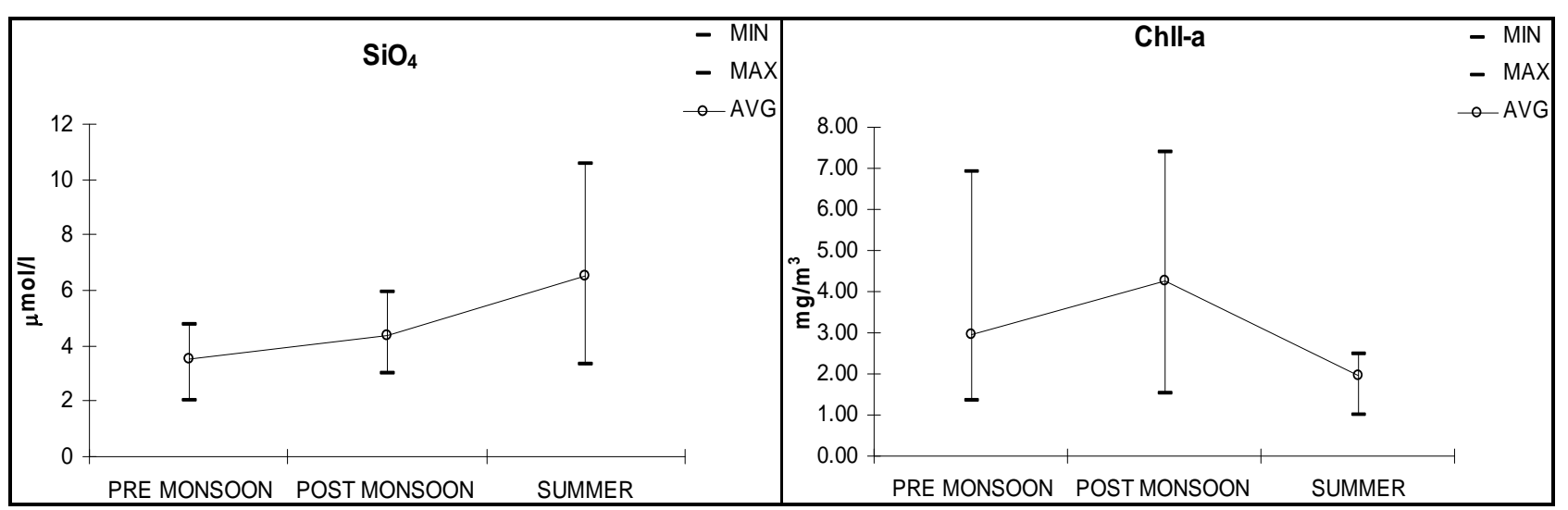

Figure 2. Seasonal variation of physicochemical parameters with standard deviation and its relation in variables of Mahanadi estuary in the years 2008-10.

activities at the estuary also affect the water quality. Atharbanki Creek is heavily loaded with the most of the municipal sewage of Paradip Township and effluents from industries such as Paradip Phosphate Limited (PPL) and passes it to Mahanadi estuary, which is due to influx of solid wastes from the Phosphatic fertilizer plants situated in the estuarine region. These wastes are allowed to join the sewers untreated bodies and create contaminations. During summer, reduced water volume and accelerated growth of microbes in higher temperature are responsible for higher degradation of organic matter, which eventually depleted the DO concentration. Domestic sewage appears to be the major source of pollutant in these water bodies. Results also indicate that the Mahanadi estuary with such overloaded situation cannot sustain any further sewage discharge. If proper alternative arrangements like sewage treatment before discharge are not made then the situation may be alarming to the inhabitants in the study area and to the downstream as well. Thus, adequate attempts have to be made to treat the waste water before discharging it to the water bodies to keep the marine environment healthy.

\section{Acknowledgements}

The authors would like to acknowledge the encouragements from Director, Institute of Minerals and Materials Technology (CSIR), Bhubaneswar, Founder of KIIT University, Bhubaneswar for their continuous moral support and financial Support by MoES, Govt. of India and without which this innovative activities would not have been possible.

\section{REFERENCES}

[1] R. Pai and M. P. M. Reddy, "Distribution of Nutrients of Malpe, South Kanara Coast," Indian Journal of Marine Science, Vol. 10, No. 4, 1981, pp. 322-326.

[2] G. J. Chakrapani and V. Subramanian, "Rate of Erosion and Sedimentation in the Mahanadi River Basin, India," Journal of Hydrology, Vol. 149, No. 1-4, 1993, pp. 39-48. doi:10.1016/0022-1694(93)90098-T

[3] B. B. Nayak, J. Das, U. C. Panda and B. C. Acharya, "Industrial Effluents and Muncipal Sewage Contamination of Mahanadi Estuarine Water, Orissa," Proceedings, Published Allied Publishers Pvt. Ltd., New Delhi, India, 2002, pp. 77-86.

[4] B. B. Nayak, B. N. Sahoo, B. C. Acharya and R. K. Sahoo, "Studies on Water and Sediment Qualities around Dhamara Estuary, Orissa," Vistas in Geological Research, Utkal University Spl. Publication in Geology, Vol. 2, 1997, pp. 243-250.

[5] I. Radhakrishna, "Saline Fresh Water Interface Structure in Mahanadi Delta Region, Orissa, India," Environmental Geology, Vol. 40, No. 3, 2001, pp. 369-380. doi:10.1007/s002540000182

[6] S. K. Sundaray, U. C. Panda, B. B. Nayak and D. Bhatta, "Behaviour and Distribution Pattern of Nutrients in RiverEstuarine Waters of Mahanadi, Orissa, India," Asian Journal of Water, Environment and Pollution, Vol. 2, No. 1, 2005, pp. 77-84.

[7] S. K. Sundaray, U. C. Panda, B. B. Nayak and D. Bhatta, "Multivariate Statistical Techniques for the Evaluation of Spatial and Temporal Variation in Water Quality of the Mahanadi River-Estuarine System (India)-A Case Study," Environmental Geochemistry and Health, Vol. 28, No. 4, 2006, pp. 317-330.

[8] K. O. Konhauser, M. A. Powell, W. S. Fife, F. J. Longstaffle and S. Tripathy, "Trace Element Geochemistry of River Sediment, Orissa State, India," Journal of Hydrology, Vol. 193, No. 1-4, 1997, pp. 258-269.

[9] K. Sarala Devi, V. N. Sankaranarayanan and P. Venugopal, "Distribution of Nutrients in the Periyar River Estuary," Indian Journal of Marine Sciences, Vol. 20, 1991, pp. 4954.

[10] G. J. Chakrapani and V. Subramanian, "Preliminary Studies on the Geochemistry of the Mahanadi Basin, India," Chemical Geology, Vol. 81, No. 3, 1990, pp. 241253. doi:10.1016/0009-2541(90)90118-Q

[11] M. Vega, R. Pardo, E. Barrado and L. Deban, "Assess- 
ment of Seasonal and Polluting Effects on the Quality of River Water by Exploratory Data Analysis," Water Research, Vol. 32, No. 12, 1998, pp. 3581-3592. doi:10.1016/S0043-1354(98)00138-9

[12] S. N Desouza, R. Sengupta, S. Sanzigiri and M. D. Rajgopal, "Studies on Nutrients of Mandovi and Zuari River Systems," Indian Journal of Marine Sciences, Vol. 10, 1981, pp. 314-321. doi:10.1007/s10653-005-9001-5

[13] U. C. Panda, S. K. Sundaray, P. Rath, B. B. Nayak and D. Bhatta, "Application of Factor and Cluster Analysis for Characterization of River and Estuarine Water SystemA Case Study, Mahanadi River (India)," Journal of Hydrology, Vol. 331, No. 3-4, 2006, pp. 434-445. doi:10.1016/j.jhydrol.2006.05.029

[14] APHA, AWWA, WEF, "Standard Methods for the Examination of Water and Waste Water," 20th Edition, American Public Health Association, Washington DC, 1998.

[15] K. Grasshoff, M. Ehrhardt and K. Bkremling, "Methods of Seawater Analysis," Wiley-VCH, Hoboken, 1999, pp. $159-226$

[16] J. D. H. Strickland and T. K, Parsons "A Practical Hand Book of Seawater Analysis," Bulletin. Fisheries Research Board of Canada, Vol. 167, 1972, p. 172.

[17] S. Upadhyay, "Physico-Chemical Characteristics of the Mahanadi Estuarine Eco-System, East Coast of India," Indian Journal of Marine Science, Vol. 17, 1988, pp. 19-23.

[18] J. Das, S. N. Das and R. K. Sahoo, "Semidiurnal Variation of Some Physico-Chemical Parameters in the Mahanadi Estuary, East Coast of India," Indian Journal of Marine Science, Vol. 26, 1997, pp. 323-326.
[19] A. K. Bhattacharya, A. Choudhury and A. Mitra "Seasonal Distribution of Nutrients and Its Biological Importance in Upper Stretch of Gangetic West Bengal," Indian Journal of Environment and Ecoplanning, Vol. 6, No. 3, 2002. pp. 421-424.

[20] C. B. Sharma and N. C. Ghose, "Pollution of the River Ganga by Municipal Waste: A Case Study from Patna," Journal of the Geological Society of India, Vol. 30, No. 5, 1987, pp. 369-385.

[21] A. K. Bhattacharya, A. Choudhury and A. Mitra "Seasonal Distribution of Nutrients and Its Biological Importance in Upper Stretch of Gangetic West Bengal," Indian Journal of Environment and Ecoplanning, Vol. 6, No. 3, 2002. pp. 421-424.

[22] R. Gouda and R. C. Panigrahy, "Seasonal Distribution and Behaviour of Silicate in the Rushikulya Estuary, East Coast of India," Indian Journal of Marine Sciences, Vol. 21, No. 2, 1992, pp. 111-115.

[23] P. K. Panigrahy, J. Das, S. N. Das and R. K. Sahoo, "Evaluation of the Influence of Various Physico-Chemical Parameters on Coastal Water Quality, around Orissa, by factor Analysis," Indian Journal of Marine Sciences, Vol. 28, No. 4, 1999, pp. 360-364.

[24] S. K. Sundaray, U. C. Panda, B. B. Nayak and D. Bhatta, "Multivariate Statistical Techniques for the Evaluation of Spatial and Temporal Variation in Water Quality of the Mahanadi River-Estuarine System (India)-A Case Study," Environmental Geochemistry and Health, Vol. 28, No. 4, 2006, pp. 317-330. 